\title{
As construções metafóricas de aprendizes de inglês sobre seu papel na aprendizagem de uma língua adicional
}

\author{
Metaphorical constructions of english language learners about their role in \\ learning an additional language
}

\author{
Marina Morena dos Santos e Silva \\ Universidade Federal de Minas Gerais - UFMG - Belo Horizonte - Minas Gerais - Brasil
}

\begin{abstract}
Resumo: $O$ foco do trabalho a ser apresentado está no modo como a imagem do aluno é construída no discurso de aprendizes adolescentes de inglês como língua adicional, com base em um corpus constituído de 64 narrativas de aprendizagem. As metáforas encontradas foram analisadas qualitativamente à luz das teorias da Metáfora Conceptual (LAKOFF e JOHNSON, 1980) e dos Esquemas Imagéticos (LAKOFF, 1987). A partir da análise, evidencia-se que este grupo de aprendizes se conceptualiza como trabalhadores, máquinas, contêineres e construtores. Fica evidente, portanto, a necessidade da realização de pesquisas sobre esse tema para proporcionar um desenvolvimento reflexivo por parte de professores e pesquisadores acerca do processo de ensino e aprendizagem desse idioma, nos dias atuais.
\end{abstract}

Palavras-chave: Metáforas. Aprendiz. Aprendizagem de Língua Inglesa.

Abstract: Based on a corpus composed of 64 Language Learning Histories, the article focuses on the way the image of learners is talked about metaphorically in young English language learners' discourse. The metaphors found were qualitatively analyzed according to the Conceptual Metaphor Theory (LAKOFF \& JOHNSON, 1980) and the Image Schemas (LAKOFF, 1987). The results show that the group of learners investigated conceptualizes themselves as workers, machines, containers and builders. It thus, seems clear that there is a need to conduct research on this topic to provide reflective development by teachers and researchers about the teaching and learning process of this language nowadays.

Keywords: Metaphors. Learner. English Language Learning. 


\section{Introdução}

A metáfora é objeto de estudo desde a antiguidade clássica até os dias atuais. Muito se discutiu e ainda se discute sobre o processo metafórico e sua importância em relação à linguagem. Extremamente complexa e ao mesmo tempo fascinante, ela é estudada em diversas áreas como a Linguística, a Psicologia e a Filosofia. Compreender a metáfora, no entanto, é uma tarefa árdua, o que faz com que diferentes posturas metodológicas sejam adotadas.

$\mathrm{Na}$ visão tradicional $^{1}$, a metáfora era considerada a partir de seu valor estético e seu estudo ficava limitado à Literatura. Contudo, com as mudanças em diversas áreas do conhecimento e com o rompimento de alguns paradigmas, o significado passou a ser entendido como uma construção cognitiva, de modo que as palavras não mais continham significados, mas sim orientavam a construção de sentido (FERRARI, 2011, p. 14). Nesse paradigma, a metáfora passou a ser compreendida como um fenômeno cognitivo fundamental que, embora percebida na linguagem, está em nossas mentes, conectada às nossas ações, estruturando nossos pensamentos. Como defende a Linguística Cognitiva, seu significado e sua interpretação dependem do modo como o mundo é apreendido e experienciado. No discurso educacional, a metáfora investiga algo essencial: como pensamos, conceptualizamos e compreendemos uns aos outros (CAMERON, 2003), tornando-se, portanto, um instrumento valioso, que, como afirma Swales (1994), proporciona insights sobre a educação que, construídos culturalmente, precisam ser analisados e reinterpretados, principalmente, através do ponto de vista dos estudantes.

Considerando, portanto, a metáfora como um caminho de construção do conhecimento, este trabalho, cujos dados são um recorte de uma pesquisa de mestrado, apresenta a voz desses

\footnotetext{
${ }^{1} \mathrm{O}$ termo 'tradicional' está sendo usado apenas com o objetivo de marcar uma ruptura paradigmática e fazer, portanto, um recorte temporal, no intuito de diferenciar os pesquisadores que adotaram uma abordagem mais contemporânea da metáfora.
}

estudantes. Optamos por aqui apresentar, à luz das teorias de Lakoff e Johnson (1980) e Lakoff (1987), as conceptualizações de aprendizes adolescentes de Língua Inglesa (LI), como língua adicional, sobre si mesmos, agentes no processo de ensino e aprendizagem. Acreditamos que muitos trabalhos de metáforas de aprendizagem evidenciam as conceptualizações de professores, deixando de evidenciar atores fundamentais no processo: os alunos. Entendemos que explorar as metáforas utilizadas pelos aprendizes é compreender seus pensamentos, crenças e conceptualizações. As metáforas tornam-se objetos de análise importantes, que podem revelar aspectos interessantes que subjazem as ações desse grupo de aprendizes em sala de aula e podem revelar novos caminhos a serem trilhados tanto pelos professores, quanto pelos alunos.

O presente estudo será apresentado em seis seções incluindo esta introdução. Na seção seguinte, abordamos a Teoria da Metáfora Conceptual (LAKOFF e JOHNSON, 1980) e as metáforas de Esquemas Imagéticos (LAKOFF, 1987), que analisam a metáfora como dependentes de nossas experiências sensório-motoras, emocionais e sociais (LAKOFF, 1987). Na seção 3, apresentamos uma breve revisão dos trabalhos que investigaram as metáforas de alunos no contexto de ensino de uma língua adicional. $\mathrm{Na}$ seção 4, a pesquisa é contextualizada e os procedimentos metodológicos adotados, descritos. $\mathrm{Na}$ seção 5 , apresentamos a análise e a discussão das metáforas identificadas nas narrativas dos participantes. $\mathrm{Na}$ última seção, trazemos as considerações finais deste artigo, buscando contribuir com os estudos da metáfora nas áreas da Linguística Cognitiva e da Linguística Aplicada (LA).

\section{Metáfora: interpretando experiências}

Formulada por Lakoff e Johnson (1980) e considerada, principalmente como do domínio da Linguística Cognitiva, a Teoria da Metáfora Conceptual é tida como um marco fundamental para 
os estudos da metáfora, não por ser a única, mas por ser a teoria mais popular a compreender que os seres humanos são dotados de um sistema conceptual metafórico e que nossas experiências, percepção de mundo, comportamento e relacionamento com outras pessoas podem ser entendidos e estruturados a partir das metáforas existentes em nossa cultura.

De acordo com Kövecses (2002, p. 4), "na visão da Linguística Cognitiva, a metáfora é definida como a compreensão de um domínio conceptual em termos de outro domínio conceptual", de modo que os conceitos metafóricos estruturam parcialmente uma experiência em termos de outra (LAKOFF e JOHNSON, 1980). Dessa maneira, é possível perceber como as pessoas conceptualizam discussão em termos de guerra, amor em termos de viagem e tempo em termos de dinheiro, por exemplo, dando origem à seguinte visão: DOMINIO CONCEPTUAL (A) É DOMINIO CONCEPTUAL (B), sendo domínio descrito, por Kövecses (2002, p. 4), como "qualquer organização coerente da experiência". Sob esta perspectiva, teríamos as metáforas conceptuais DISCUSSÃO É GUERRA, AMOR É UMA VIAGEM e TEMPO É DINHEIRO.

Na metáfora AMOR É UMA VIAGEM, por exemplo, temos os domínios AMOR (domínio alvo) e VIAGEM (domínio fonte), de modo que o mapeamento ocorre entre esses dois domínios da experiência. Contudo, a metáfora não é apresentada em nosso cotidiano dessa forma, mas sim através de expressões linguísticas metafóricas que são manifestações dessa metáfora conceptual. Logo, em situações da vida real, nos depararíamos com expressões como "Veja a que ponto chegamos" ou "Temos que simplesmente seguir caminhos separados" (LAKOFF e JOHNSON, 2002, p. 104), sendo o significado da metáfora constituído pelo mapeamento entre o domínio alvo e o domínio fonte, ou seja, pelo "conjunto de correspondências sistemáticas entre a fonte e o alvo no sentido de que elementos conceptuais constitutivos de $B$ correspondem aos elementos constitutivos de A" (KÖVECSES, 2002, p. 6, grifo do autor). Logo, podemos ter, segundo Sardinha (2007, p. 31), o seguinte mapeamento para a metáfora conceptual AMOR É UMA VIAGEM:

\begin{tabular}{|c|c|c|}
\hline Viajantes & $\leftrightarrow$ & $\begin{array}{l}\text { Amantes ou marido e } \\
\text { mulher }\end{array}$ \\
\hline agem & $\leftrightarrow$ & $\begin{array}{l}\text { Planos futuros da vida } \\
\text { a dois }\end{array}$ \\
\hline da viagem & $\leftrightarrow$ & Relação feliz a dois \\
\hline $\begin{array}{l}\text { ocamento } \\
\text { uilo da viagem } \\
\text { ocamento }\end{array}$ & $\leftrightarrow$ & $\begin{array}{l}\text { Relação sem } \\
\text { problemas } \\
\text { Relacão com }\end{array}$ \\
\hline $\begin{array}{l}\text { nuo e previsível } \\
\text { agem }\end{array}$ & $\leftrightarrow$ & $\begin{array}{l}\text { problemas, devido à } \\
\text { monotonia }\end{array}$ \\
\hline $\begin{array}{l}\text { gar carona na } \\
\text { gem }\end{array}$ & $\leftrightarrow$ & $\begin{array}{l}\text { Ter um caso fora do } \\
\text { relacionamento }\end{array}$ \\
\hline
\end{tabular}

As metáforas podem ser ainda, de acordo com Kövecses (2002), baseadas em imagens convencionais, que derivam de nossas experiências e interação com o mundo: as metáforas de esquemas imagéticos. Ao explorarmos objetos físicos a partir de nosso contato com eles, experimentaríamos nosso corpo e os outros objetos como contêineres, por exemplo; ou ainda, experimentamos forças físicas em nosso cotidiano, como a força gravitacional ou a força magnética, que podem nos afetar e exercer certa influência sobre nós. Logo, experiências básicas e corriqueiras como essas dariam origem aos esquemas imagéticos e, consequentemente, a muitos de nossos conceitos metafóricos abstratos. Lakoff (1987, p. 267) aponta alguns exemplos de esquemas imagéticos, como os esquemas que surgem a partir de nossa experiência corporal cotidiana CONTÊINERES, CAMINHOS, LIGAÇÃO, FORÇAS e EQUILÍBRIO - e a partir de orientações e relações CIMA-BAIXO, FRENTE-TRÁS, PARTE-TODO, CENTRO-PERIFERIA. Portanto, podemos perceber que a motivação metáforica é predominantemente experiencial. As metáforas conceptuais que usamos e o modo como as interpretamos podem ser influenciados por nossas experiências fisiológicas, motoras e perceptuais, mas também pelo contexto sociocultural no qual estamos inseridos, já que nosso corpo funciona em um contexto específico, não está isolado nem livre de influências. A utilização de metáforas é, portanto, diretamente influenciada por nossa cultura. 


\section{As representações metafóricas de alunos em pesquisas de LA}

Swales (1994) afirma que é preciso entender o que o processo de aprendizagem de uma língua significa para professores e alunos, e um modo de se conseguir isso é através do incentivo à elaboração de metáforas. Ao aprender um idioma, os alunos criam sua própria construção de mundo através das interações sociais das quais participam (OXFORD, 2001), sendo a interação professor-aluno uma das mais intensas e importantes. Assim, as metáforas utilizadas por esses aprendizes são muitas vezes, de acordo com Ellis (2001), convencionalizadas e refletem suas percepções sobre o processo de ensino e aprendizagem.

Dos trabalhos dedicados aos estudos de metáforas de aprendizagem, a maioria foca as metáforas que emergem do discurso de professores e/ou sobre professores de língua adicional. Poucos pesquisadores buscam identificar quais as metáforas utilizadas pelos próprios alunos e como seus papéis são percebidos e representados na sala de aula de língua adicional.

As metáforas identificadas por esses pesquisadores demonstram que embora 0 conhecimento, atualmente, seja concebido mais como um processo de construção e conexão a partir das múltiplas relações que estabelecemos no nosso cotidiano, o aluno ainda é conceptualizado, principalmente, como sujeito passivo e sem autonomia sobre sua aprendizagem, corroborando a metáfora da aprendizagem como uma transmissão, que vigorou durante muitos anos no discurso de teóricos e profissionais da educação.

Como é possível observar no QUADRO 1, as metáforas identificadas nas pesquisas supracitadas revelam múltiplos papéis para os alunos: negociador, construtor, investidor, máquina, viajante, dentre outros. Algumas metáforas mostram os alunos como sujeitos que desempenham um papel importante no processo de aprendizagem de uma língua adicional, como é o caso da metáfora predominante no discurso de professores e alunos, no trabalho basilar de Block (1992).

Block (1992) realizou um estudo cujo objetivo principal era investigar se as metáforas nos discursos de professores e de alunos de uma escola de idiomas de Barcelona condiziam com as metáforas que apareciam em trabalhos recentes da área de LA daquela época. Para isso, o autor analisou o discurso de 22 aprendizes e de 14 professores de LI como língua adicional. Após a análise dos dados, constatou que os professores usavam metáforas similares àquelas usadas pelos linguistas aplicados, a saber, $O$ APRENDIZ É UM CLIENTE ATIVO, que segundo Block (1992), demonstra uma visão de professores que facilitam o aprendizado, ao invés de ensinar seus alunos. Já os alunos apresentavam o mesmo modelo de seus professores, no entanto, focavam principalmente o professor e demonstravam mais uma atitude de reciprocidade quanto às ações dos professores do que uma atitude ativa quanto à sua aprendizagem.

Quadro 1 - $O$ aprendiz de inglês em pesquisas na LA

\begin{tabular}{|c|c|c|}
\hline \multicolumn{3}{|c|}{ APRENDIZ É } \\
\hline $\begin{array}{l}\text { BLOCK } \\
\text { (1992) }\end{array}$ & ELLIS (2001) & $\begin{array}{l}\text { ARAÚJO E SOL } \\
(2006)\end{array}$ \\
\hline $\begin{array}{l}\text { - CLIENTE } \\
\text { ATIVO }\end{array}$ & $\begin{array}{l}\text { - CONTÉINER } \\
\text { - MÁQUINA } \\
\text { - NEGOCIADOR } \\
\text {-SOLUCIONADOR DE } \\
\text { PROBLEMAS } \\
\text { - CONSTRUTOR } \\
\text { - LUTADOR/ALGUÉM } \\
\text { QUE SE ESFORÇA } \\
\text { - INVESTIDOR } \\
\text { - SOFREDOR } \\
\text { - VIAJANTE } \\
\text { - TRABALHADOR }\end{array}$ & $\begin{array}{l}\text { - CONTÊINER / } \\
\text { RECEPTOR } \\
\text { - CONSTRUTOR } \\
\text { - SOFREDOR } \\
\text { - VIAJANTE } \\
\text { - MÁQUINA }\end{array}$ \\
\hline
\end{tabular}

Já a pesquisa de Ellis (2001), que teve como objetivo principal investigar como os pesquisadores de Aquisição de Segunda Língua constroem a imagem dos alunos e como esses alunos constroem a si mesmos, revelou que (1) os aprendizes caracterizam-se como agentes do seu aprendizado e demonstram ser críticos quanto a si mesmos e quanto a seus professores e (2) os alunos demonstram consciência não apenas sobre a dimensão cognitiva, mas também sobre a dimensão afetiva de sua aprendizagem. 
No contexto brasileiro, Araújo e Sól (2006) realizaram um estudo sobre as metáforas utilizadas por professores e alunos da rede pública de ensino ao definirem o professor e o aluno de $\mathrm{LI}$ e constataram que as metáforas mais utilizadas apareceram na seguinte ordem de frequência: CONTÊINER/RECEPTOR, CONSTRUTOR, SOFREDOR, VIAJANTE e MÁQUINA. Desse modo, os resultados indicam que as metáforas utilizadas por esses aprendizes e esses professores ainda estão relacionadas aos métodos e às concepções de ensino mais tradicionais.

Assim, a partir da leitura e análise desses trabalhos, constata-se o quanto uma pesquisa mais detalhadas das metáforas de aprendizagem se faz necessária em nosso contexto educacional, em especial, apresentando o processo de aprendizagem do ponto de vista dos próprios alunos, a partir de seus discursos. Dessa maneira, este trabalho retoma, com algumas adaptações, parte dos resultados de uma pesquisa de mestrado que objetivou a identificação, classificação e interpretação de metáforas, em narrativas multimodais de aprendizagem de LI, de alunos de uma escola da rede particular da região metropolitana de Belo Horizonte, buscando ajudar na discussão das metáforas que alunos de LI, como língua adicional, utilizam para falar de si mesmos e corroborar trabalhos anteriores que desenvolveram esse tema.

\section{A pesquisa}

A pesquisa foi realizada em uma escola particular localizada na região metropolitana de Belo Horizonte. Os 64 estudantes convidados a participar desta pesquisa faziam parte de cinco turmas da escola: $8^{\circ}$ e $9^{\circ}$ ano do Ensino Fundamental e $1^{\underline{a}}, 2^{\underline{a}}$ e $3^{\text {a }}$ série do Ensino Médio. A escolha dessas turmas deu-se pelo fato de alunos de escolas regulares e dessa faixa etária (GRÁFICO 1) não serem, normalmente, sujeitos de pesquisas sobre metáforas de aprendizagem.

\section{Gráfico 1 - Perfil dos participantes por idade}

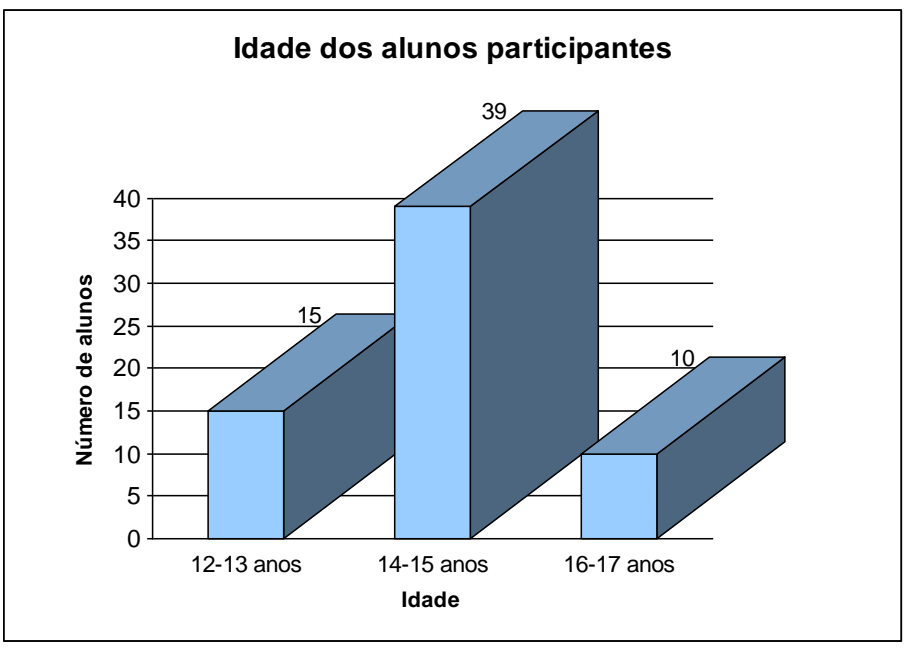

Fonte: elaborado pela autora deste trabalho

O instrumento utilizado nesta pesquisa para a coleta de dados foi a escrita de narrativas multimodais de aprendizagem, que possibilitam o acesso às experiências desses aprendizes, bem como a suas percepções, crenças e anseios quanto ao processo de ensino e aprendizagem de LI. Essas histórias pessoais acabam por representar a complexidade dos fenômenos com os quais lidamos diariamente e demonstram que a partir de seu estudo podemos acessar não apenas as individualidades daquele aprendiz, mas também um sistema de significação construído social e culturalmente.

Desse modo, foi pedido aos alunos que escrevessem sobre suas memórias quanto ao processo de ensino e aprendizagem de LI, considerando, por exemplo, as escolas e/ou cursos de idiomas que frequentaram, os professores com os quais conviveram e todos os artefatos culturais que influenciaram sua aprendizagem. Antes da elaboração das narrativas, os alunos foram orientados quanto à criação de um texto multimodal/multimídia para que soubessem usar os recursos necessários no editor de textos Microsoft Office Word, o editor de texto usado por eles. É importante ressaltar que nenhuma orientação ou instrução quanto ao tema desta pesquisa foi dada aos participantes. As revisões dos textos focaram na tentativa de criação de um texto multimodal/multimídia, já que o objetivo final não era a escrita de acordo com a norma culta da língua 
portuguesa, nem a indução de metáforas em seus discursos. Nosso objetivo era que as metáforas emergissem naturalmente e que os alunos contassem suas histórias expressando-se de múltiplas formas.

Para orientar a escrita da narrativa, como se trata de um público inexperiente quanto à elaboração de textos e reflexões desse tipo, os aprendizes receberam um roteiro como orientação para a escrita. Neste roteiro, alguns tópicos eram sugeridos, tais como: estratégias e dificuldades ao aprender 0 idioma, a importância da língua, os pontos positivos e os negativos de suas experiências com a aprendizagem de $\mathrm{LI}$, expectativas em relação à $\mathrm{LI}$, dentre outros.

No total, foram coletadas 64 narrativas, analisadas qualitativamente, à luz da Teoria da Metáfora Conceptual (LAKOFF e JOHNSON, 1980) e dos Esquemas Imagéticos (LAKOFF, 1987), e organizadas quantitativamente, de acordo com a regularidade de seus domínios.

Para salvaguardar a identidade dos aprendizes, todos eles tiveram seus verdadeiros nomes omitidos. Assim, um código de identificação, criado a partir dos nomes e das séries dos participantes, foi utilizado para que os autores dos trechos apresentados pudessem ser identificados.

\section{Resultados}

As metáforas sobre aprendizes de LI puderam ser identificadas em 22 narrativas diferentes, 34,38\% dos dados, com 27 ocorrências, no total. Os domínios fonte mais utilizados pelos alunos investigados para descreverem a si mesmos aparecem, como pode ser observado no GRÁFICO 2, na seguinte ordem de frequência: trabalhador/alguém que se esforça, máquina, contêiner e construtor. Apenas um deles (contêiner) é uma Metáfora de Esquema Imagético, totalizando $11,11 \%$ das ocorrências identificadas.
Gráfico 2 - Aprendiz de inglês - Número de narrativas por domínio fonte

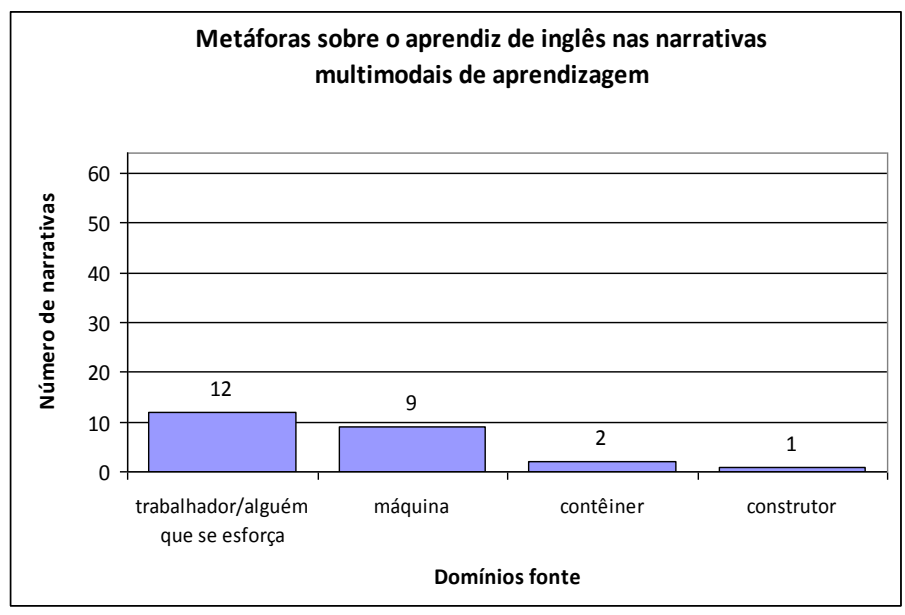

Fonte: elaborado pela autora deste trabalho

\section{APRENDIZ DE INGLÊS É TRABALHADOR/ALGUÉM QUE SE ESFORÇA}

A primeira metáfora identificada conceptualiza os aprendizes como trabalhadores, pessoas que se esforçam, totalizando 13 ocorrências, 48,15\% das metáforas referentes ao domínio alvo aprendiz de inglês, aparecendo em 12 narrativas, 18,75\% dos dados.

A partir dessa metáfora, o aprendiz parece ser conceptualizado como um trabalhador dedicado e esforçado, que precisa empenhar-se para conseguir realizar sua tarefa: aprender o idioma. Nos excertos \# 1 a \# 5, é possível encontrar verbos que indicam uma situação relacionada ao trabalho. Aqui, não nos referimos especificamente ao trabalho como uma atividade profissional remunerada, mas sim como empenho e esforço para execução de algo e/ou a realização de uma série de atividades para um determinado fim.

\#1 [...] tenho trabalhado para melhor entender a língua e ter menos dificuldades. Th8

\#2 Estudar inglês não é nenhum "mamão com açúcar". $\mathrm{Na}$ verdade é bem difícil a sua gramática, e seu vocabulário que é tão diferente do português. Exige de nós vontade, esforço e dedicação. Ma8

\#3 Quando nós somos conscientes de que o aprendizado de inglês é essencial para nos dar bem na vida, só existe uma coisa a fazer: Arregaçar as mangas e enfrentar a fera. Ma8 \#4 [...] demorei muito para perceber que o inglês e fácil, mas para isso temos muito trabalho duro para fazer, temos de nos 
empenhar mais temos de chegar e sentir e ver que eu consigo, é só ter vontade, tem de dar o melhor [...] Tu8

\#5 É um idioma complicado, e as aulas exigem muita dedicação e esforço do aluno, [...] Ca9

Ao afirmar que tem trabalhado para aprender o idioma, ou que precisa ou tem se esforçado, o aluno conceptualiza metaforicamente a aprendizagem como uma atividade que merece cuidado e esmero. No entanto, esta atividade não é uma atividade qualquer, é uma atividade difícil, um "trabalho duro", que exige não apenas interesse e esforço, mas também empenho e dedicação, cabendo ao aluno agir para que o aprendizado aconteça. Dessa maneira, a LI é conceptualizada mais como um desafio, um problema a ser enfrentado, pois é um idioma "difícil", "complicado", "não é nenhum mamão com açúcar". No entanto, os aprendizes demonstram ter consciência de suas "dificuldades", afirmando que é preciso "arregaçar as mangas". Em suas narrativas, eles dizem, portanto, buscar solucionar problemas e realizar as atividades no intuito de aprender o idioma. Essa metáfora, como aponta Ellis (2001, p. 81), "parece ser usada para se referir à ideia de esforço autodirecionado na aprendizagem e relacionado à construção de motivação". Os aprendizes parecem querer demonstrar o quanto se dedicam aos estudos ou ao menos possuir a consciência de que precisam se dedicar. Além disso, essa metáfora parece colocar os aprendizes como sujeitos ativos cognitivamente, pois eles sabem que 0 resultado final da aprendizagem depende deles, pois são eles que devem "trabalhar" para que isso aconteça.

\section{APRENDIZ DE INGLÊS É UMA MÁQUINA}

Outra metáfora bem recorrente nas narrativas de aprendizagem dos alunos investigados foi a conceptualização dos aprendizes como máquinas, que apareceu em nove narrativas, $14,06 \%$ dos dados, com dez ocorrências, 37,04\% das ocorrências sobre aprendizes de inglês. A seguir, apresentamos algumas ocorrências dessa metáfora.
\#1 A minha dificuldade no inglês é que eu não consigo gravar a maioria das palavras [...] AnL8 \#2 [...] não consigo gravar o significado das palavras ou até mesmo a palavra [...] JoV8

\#3 Uma estratégia que acho muito boa para aprender a matéria é através de músicas, pois consigo gravar a pronúncia quando ouço a canção e leio a letra. Ra8

\#4 Eu uso sempre o método de resumir o conteúdo, ler várias vezes e relembrar antes das provas, para fixar melhor a matéria. Ma8

\#5 Minha principal dificuldade é gravar as regras e pronunciar algumas palavras. Luc9

\#6 Ainda não desenvolvi nenhuma técnica que me ajudasse a gravar essas regras e coisa e tal, mas continuo tentando decorar. PeR9

\#7 Eu posso dizer que isso influenciou na minha aprendizagem, por que eu sempre estou vendo letras e traduções de músicas em inglês e acabo que gravando, automaticamente, vocabulários na minha cabeça. MaC2

Aqui, o aprendiz, especialmente o seu cérebro, parece ser conceptualizado como um gravador, ou um disco rígido, que "grava" palavras, significados, pronúncia, vocabulário e, principalmente, regras gramaticais, "fixando" o conteúdo da disciplina.

Segundo Ellis (2001), esta é uma das metáforas mais recorrentes na fala de pesquisadores de Aquisição de Segunda Língua, sendo o computador, possivelmente, a máquina à qual eles se referem. Assim, teríamos uma derivação ou extensão da metáfora O CÉREBRO É UM COMPUTADOR. Ainda segundo Ellis (2001), a metáfora O APRENDIZ É UMA MÁQUINA colocaria os aprendizes como não tendo controle sobre o que eles fazem ou sobre o modo como eles aprendem, pois eles não controlariam como a máquina funciona ou a capacidade dela, tudo aconteceria automaticamente. Ao analisar as expressões metafóricas das narrativas coletadas, tal afirmação parece ficar evidente, pois os alunos afirmam "gravar" as coisas "automaticamente". Desse modo, eles não parecem ter total controle sobre o modo como ela opera e, portanto, não têm controle sobre o que fazer e como fazer para aprender a língua.

Outro fato que fica evidente nessa metáfora é a importância dada pelos alunos a um conhecimento explícito das regras do idioma, pois ao utilizarmos o domínio máquina, podemos inferir que essa máquina recebe um input, que se transforma no conhecimento aprendido pelo aluno (intake). Das dez ocorrências, 
em quatro, podemos mapear as regras gramaticais como sendo esse input, ou seja, o que vai para a máquina. Assim, os alunos parecem acreditar que saber uma regra gramatical conscientemente é parte necessária da aprendizagem de uma língua.

\section{APRENDIZ DE INGLÊS É UM CONTÊINER}

O aprendiz sendo conceptualizado a partir do domínio fonte contêiner apareceu em duas narrativas, $3,13 \%$ dos dados, e teve três ocorrências, num total de $11,11 \%$, evidenciando o papel passivo do aluno ainda nos dias atuais.

\#1 [...] vejo que se quero ter um bom futuro, tenho de absorver as coisas boas agora, é aí que o inglês entra, [...] Na8

\#2 [...] ótimos e severos professores que me ensinarão tudo o que sei e guardo com carinho [...] $\mathrm{Na} 8$

Nessa metáfora, podemos entender os aprendizes como contêineres e, portanto, como objetos que podem conter algo - neste caso, o conhecimento sobre a língua - e podem ter esse conteúdo inserido dentro deles. Por isso, os alunos utilizam itens lexicais como 'absorver', 'entrar' e 'guardar' para se referir ao idioma e/ou às lembranças do processo de aprendizagem deste. É como se esses aprendizes e, especificamente, suas cabeças fossem contêineres onde o conhecimento possa ser inserido ou retirado a qualquer momento.

Essa metáfora relaciona-se com a metáfora do conduto de Reddy (1979) que observou que a comunicação verbal era descrita e estruturada por metáforas que a conceptualizavam como uma transmissão, como se objetos fossem colocados em pacotes, pelo emissor, e enviados ao interlocutor utilizando-se um canal. O interlocutor, por sua vez era responsável por retirar esses objetos do recipiente e fazer com que a comunicação fosse realizada.

Ao explicitarem essa metáfora (CONTÊINER), os alunos parecem se conceptualizar como destituídos de autonomia, controle e expectativas, sendo influenciados pelo ambiente externo e demonstrando, portanto, como afirmam Araújo e Sol
(2006, s/d), ser uma figura passiva e domesticada "que apenas decora e obedece as ordens do professor". Ellis (2001) afirma ainda que, a partir dessa metáfora, podemos perceber que os alunos são entendidos como restritos, pois têm uma capacidade limite para a aprendizagem tanto em relação ao que podem compreender quanto em relação ao que podem recordar. Embora não tenha aparecido nenhum item lexical que indicasse uma capacidade limite, esses alunos, enquanto contêineres, podem ser entendidos dessa forma, pois são apenas receptores, o que também é uma limitação.

\section{APRENDIZ DE INGLÊS É UM CONSTRUTOR}

Por fim, a última metáfora identificada conceptualiza o aprendiz como um construtor e obteve apenas uma ocorrência, 3,70\% das ocorrências, sendo identificada em apenas uma narrativa, $1,56 \%$ dos dados.

\#1 [...] o inglês é importante para mim por que quem constrói o meu futuro sou eu e vejo que se quero ter um bom futuro, tenho de absorver as coisas boas agora, é aí que o inglês entra [...] $\mathrm{Na} 8$

Apenas um aprendiz projetou-se metaforicamente como aquele que "constrói o seu futuro", ou seja, como alguém responsável e consciente de sua aprendizagem, assumindo mais autonomia e atividade no processo de aprendizagem da língua-alvo. Essa metáfora relaciona-se com a teoria sociocultural de Vygotsky (1978) e com o conceito de scaffolding (WOOD, BRUNER e ROSS, 1976) e revela a contribuição ativa do aprendiz, bem como a importância e a necessidade de suporte. No entanto, ao mesmo tempo em que se caracteriza como um construtor, dizendo construir seu futuro, o aprendiz se projeta como um contêiner, afirmando que ele "absorve coisas" e "deixa o inglês entrar". Logo, há uma contradição, já que o aprendiz projetado como um contêiner não exerce um papel ativo durante o processo, mas sim um papel receptivo. 


\section{Considerações Finais}

Como evidenciaram os dados apresentados, os aprendizes sabem da importância de seu papel na aprendizagem de uma língua adicional e destacam essa participação, buscando demonstrar que, sendo esta uma atividade que merece dedicação e esmero, eles se empenham e buscam realizar as atividades de trabalho, superando desafios propostos. Vimos, ainda, ser inegável, para esses aprendizes, a aprendizagem focada na compreensão explícita de regras, que devem ser decoradas e armazenadas. Alguns aprendizes ainda se conceptualizam como sujeitos passivos, destituídos de autonomia, que aprendem o idioma de um modo automático e têm o professor como o detentor do conhecimento. Esse discurso mais tradicional de ensino, embora nem sempre represente a realidade, aparece, nas metáforas identificadas, quase que na mesma proporção das metáforas que conceituam o aprendiz como mais ativo. Block (1992) já apontava que a metáfora dos alunos como recipientes vazios e passivos e a imagem do professor como aquele que irá Ihe entregar a mercadoria, o conhecimento, é uma imagem com a qual professores se identificavam desde a década de 90. Contudo, como apontam os resultados de Araújo e Sól (2006), corroborados por este estudo, esta parece ser uma imagem com a qual os alunos brasileiros, em especial, se identificam mais, mesmo no século XXI. É possível que o uso de tal imagem justifique-se pelo que Lakoff e Turner (1989) apontam sobre o grande uso de metáforas que são mais estabelecidas conceptualmente, usadas amplamente, e, frequentemente, realizadas linguisticamente como expressões estereotipadas. As metáforas PESSOAS SÃO CONTÊINERES $\mathrm{e}$ PESSOAS SÃO MÁQUINAS são exemplos de metáforas estereotipadas e que podem, consequentemente, refletir nas metáforas utilizadas por aprendizes para conceptualizar a si mesmos da mesma forma.

No que diz respeito às diferenças entre as metáforas utilizadas por esse grupo de aprendizes e as metáforas de alunos nos trabalhos de Block (1992), Ellis (2001) e Araújo e Sól (2006), poucas diferenças foram encontradas, no que tange, especificamente, às metáforas sobre aprendizes utilizadas por pesquisadores e professores. Tal fato evidencia que mesmo em contextos e épocas totalmente diferentes os alunos são conceptualizados da mesma forma, sendo o discurso construído socialmente e repetido por gerações e gerações. Contudo, nas metáforas utilizadas pelos próprios aprendizes, a diferença mais significativa encontra-se no fato de que eles utilizaram as metáforas do contêiner, da máquina e do construtor para falarem de si mesmos apenas no contexto brasileiro. No estudo de Block (1992) e Ellis (2001), essas metáforas foram utilizadas apenas pelos pesquisadores de LA, o que pode ressaltar que, ao serem utilizadas tanto por professores e alunos, no trabalho de Araújo e Sól (2006), e pelos alunos nos dados deste trabalho, essas metáforas revelam-se mais arraigadas na cultura educacional brasileira e mais estereotipadas para esses aprendizes.

Por fim, é importante ressaltar que muitas das implicações advindas deste estudo não se destinam apenas a esses aprendizes, mas ao contexto brasileiro de ensino e aprendizagem de LI. Logo, fica evidente a necessidade de mais pesquisas, em especial, com um número maior e mais diversificado de alunos para que se possa melhor compreender a visão desses aprendizes sobre 0 processo de aprendizagem de LI. Os resultados indicam a necessidade de professores reconhecerem o papel fundamental que exercem na vida de seus estudantes e a necessidade de pesquisadores reconhecerem a importância das experiências de seus alunos para a análise do processo de ensino e aprendizagem. Ouvir os aprendizes é essencial para o ato de pesquisar e ensinar.

\section{Referências}

ARAÚJO, D. R.; SÓL, V. S. A. A análise de metáforas como meio de compreensão do processo de ensino/aprendizagem de inglês. In: SEMANA DE LETRAS, 8, 2006, Ouro Preto. Anais... Ouro Preto: UFOP, 2006. 
BLOCK, D. Metaphors we teach and learn by. Prospect, v.7, n.3, p. 42-55, 1992.

CAMERON, L. Metaphors in Educational Discourse. New York: Continuum, 2003.

ELLIS, R. The metaphorical constructions of second language learners. In: BREEN, M. Learner contributions to language learning: new directions in research. Harlow: Pearson Education, 2001. p. 65-85.

FERRARI, L. Introdução à Linguística Cognitiva. São Paulo: Editora Contexto, 2011. 171p.

KÖVECSES, Z. Metaphor: a practical introduction. Oxford: Oxford University Press, 2002. 285 p.

LAKOFF, G. Women, fire and dangerous things. Chicago: University of Chicago Press, 1987. $614 \mathrm{p}$.

LAKOFF, G.; JOHNSON, M. Metaphors we live by. Chicago: Chicago University Press, 1980. $242 \mathrm{p}$.

Metáforas da vida Cotidiana. (Coordenação da tradução: Mara Sophia Zanotto). Campinas: Mercado de Letras, 2002. 360 p.

LAKOFF, G.; TURNER, M. More Than Cool Reason: A Field Guide to Poetic Metaphor. Chicago: University of Chicago Press, 1989. 237 p.

OXFORD, R. L. 'The bleached bones of a story': learners' constructions of language teachers. In: BREEN, M. P. (Ed.). Learner contributions to language learning: new directions in research. Harlow, Essex, 2001. p. 86-111.

REDDY, M. The conduit metaphor - a case of frame conflict in our language about language. In: ORTONY, A. (Org). Metaphor and thought. Nova York: Cambridge University Press, 1979. p. 284-310.

SARDINHA, T. B. Metáfora. São Paulo: Parábola Editorial, 2007. 167 p.

SWALES, S. From metaphor to metalanguage. English teaching forum, v. 32, n. 3, p. 8-11, 1994.

VYGOTSKY, L. S. Mind in Society: The Development of Higher Psychological Processes. COLE, M. et al (Org.) Cambridge, MA: Harvard University Press, 1978.

WOOD, D.; BRUNER, J. S.; ROSS, G. The Role of Tutoring in Problem Solving. Journal of Child Psychology and Psychiatry and Allied Disciplines, v. 17, n. 2, p. 89-100, 1976. 